\title{
Expression of MIF and c-erbB-2 in endometrial cancer
}

\author{
WEI XIAO ${ }^{1,2}$, XIUJUAN DONG ${ }^{2}$, HONGHUI ZHAO $^{2}$, SHIYU HAN $^{2}$, \\ RUIXUE NIE ${ }^{2}$, XIAHUA ZHANG ${ }^{2}$ and RUIFANG AN ${ }^{1}$

\begin{abstract}
${ }^{1}$ Department of Gynaecology and Obstetrics, The First Affiliated Hospital of Xi'an Jiao Tong University, Xi'an, Shaanxi 710061;
${ }^{2}$ Department of Gynaecology and Obstetrics, The Fourth Affiliated Hospital of Harbin Medical University,
\end{abstract} \\ Harbin, Heilongjiang 150000, P.R. China
}

Received February 22, 2015; Accepted December 8, 2015

DOI: $10.3892 / \mathrm{mmr} .2016 .4992$

\begin{abstract}
The aim of the present study was to investigate the expression of c-erbB-2 and macrophage migration inhibitory factor (MIF) in endometrial cancer and to elucidate the significance of the early diagnosis and prognosis of endometrial cancer. The gene copy number of c-erbB-2 and MIF was characterized by reverse transcription quantitative polymerase chain reaction and the reactivity was assessed by immunohistochemistry in 70 patients using a polyclonal antibody, and evaluated semiquantitatively according to the percentage of cells demonstrating membranous or diffuse cytoplasmic staining. A correlation between age, tumor stage, grade, myometrial invasion and lymph node metastasis was observed. The mRNA expression of c-erbB-2 and MIF was high in endometrial carcinoma. The positive expression rate of MIF protein in normal endometrium, atypical hyperplasia and endometrial carcinoma significantly increased along with the degree of aggravation of the disease by 20 (3/15), 45 (9/20) and $70 \%$ (35/50), respectively. The positive expression of MIF and c-erbB-2 was highest in endometrial cancer and a significantly higher level of protein was observed in tumors at stage I, stage G1, with a depth of myometrial invasion $<0.4 \mathrm{~cm}$ and no lymph node metastasis. The protein expression of c-erbB-2 in endometrial cancer was higher in tumors at the G2-3 phase, clinical stage III-IV, lymph node metastasis, and had no association with the depth of myometrial invasion and age. MIF and c-erbB-2 were correlated with the occurrence and the development of endometrial cancer, and thus can be used for the early diagnosis and prognosis of endometrial cancer. The present study laid the foundation for identifying new treatments for endometrial cancer.
\end{abstract}

Correspondence to: Professor Ruifang An, Department of Gynaecology and Obstetrics, The First Affiliated Hospital of Xi'an Jiao Tong University, 277 Yanta Road, Xi'an, Shaanxi 710061, P.R. China

E-mail: ruifangan@163.com

Key words: c-erbB-2, macrophage migration inhibitory factor, endometrial cancer

\section{Introduction}

Endometrial carcinoma (EC) is the most common malignancy of the female reproductive tract. One of its symptoms is abnormal vaginal bleeding, which is similar to menstruation (1). The main treatment method is surgical resection. Several surgical pathological features of endometrial cancer have been demonstrated to correlate with prognosis. These include histological grade, histological type, depth of myometrial invasion, cervical extension and the presence of metastatic disease (2). The majority of patients are already in the advanced stage when they exhibit symptoms, leading to post-surgical relapse and a low survival rate. Therefore, methods for early diagnosis and improving prognosis are required. Non-estrogen dependent endometrial cancer has a poor prognosis, however, its pathogenesis is not clear, despite being associated with the abnormal expression of three types of genes, including oncogenes, tumor suppressor genes and DNA repair genes (3).

c-erbB-2, also termed HER-2/neu, is an oncogene in neuroblastoma cells, and is predominantly expressed in embryonic tissue and in certain normal adult tissues (4). Its proto-oncogene is located on the long arm of chromosome 17 and encodes a transmembrane tyrosine kinase receptor that has similarities to the epidermal growth factor receptor. HER-2/neu overexpression may cause abnormal cell proliferation, thus resulting in the malignant transformation of cells. The development of tumor mechanisms of c-erbB-2 include the inhibition of apoptosis, the formation of tumor blood vessels via upregulating vascular endothelial growth factor and vascular permeability factor, and increasing tumor invasiveness by eradicating the anti-invasion barrier of body tissues. However, the exact mechanism remains to be elucidated. c-erbB-2 is overexpressed in various types of tumor, including breast cancer (20-30\%), lung cancer (5), gastric cancer (6), tumors of the nervous system (7), kidney neoplasms (8), oral squamous cell carcinoma (9) and ovarian cancer (10). It has been demonstrated that c-erbB-2 can decrease tumor volume (11) and increase the survival rate in primary and secondary breast cancer (12).

Macrophage migration inhibitory factor (MIF) is a soluble factor identified during the activation of T lymphocytes (13). MIF is a unique protein, involved in inflammation, immune responses, cell growth and angiogenesis. MIF has been implicated in natural killer cell function, where it acts as an 
immunosuppressive cytokine through the inhibition of natural killer cell activity (13). MIF is suggested to be important in the occurrence and development of tumors, by increasing cell migration (14), proliferation (15) and angiogenesis (16), and is also able to inhibit p53-mediated or mitochondrial apoptosis (17). In addition, the pro-tumorigenic potential of MIF has been reported in glioblastoma multiforme $(18,19)$, ovarian cancer (20), gastric cancer (21) and non-small cell lung cancer (22).

Previous studies have reported that c-erbB-2 and MIF are associated with the occurrence and development of tumors $(23,24)$. In order to correctly identify that the targeted therapy of c-erbB-2 and MIF can benefit patients with endometrial cancer, the first and key step is to accurately detect the expression of c-erbB-2 and MIF in endometrial cancer. To the best of our knowledge, there are currently no studies on the correlation between MIF and c-erbB-2 expression in endometrial cancer. Consequently, in the present study, the expression of c-erbB-2 and MIF was detected in normal endometrial (NE), endometrial hyperplasia and endometrial cancer tissues by immunohistochemistry and reverse transcription quantitative polymerase chain reaction (RT-qPCR), and their role in the occurrence and development of endometrial cancer was discussed.

\section{Patients and methods}

Patients. A total of 80 consecutive patients between October 2012 and May 2014, including 40 with EC, 20 with endometrial hyperplasia and 15 with NE were recruited from The Fourth Hospital of Harbin Medical University (Harbin, China). Patients were aged between 40 and 82 years. The presenting symptom was postmenopausal or intermenstrual bleeding; endometrial adenocarcinoma was the most common type of cancer and was therefore selected as the cancer that would be studied. The clinicopathological parameters evaluated were age, International Federation of Gynecology and Obstetrics (FIGO) stage, type of carcinoma and depth of myometrial invasion. Among the 50 patients with EC, according to the 2009 FIGO formulation of the clinical staging criteria, there were 8 patients with stage I, 30 cases with stage II; 12 cases with stage III-IV; 37 cases with high differentiation (G1) and 13 cases with moderate/low differentiation (G2-G3); 30 cases with metastasis and 20 cases with lymph node metastasis; 29 with a uterine muscular layer of $<0.4 \mathrm{~cm}$; and 21 cases with a uterine muscular layer of $>0.4 \mathrm{~cm}$. The present study was approved by the regional ethics committee of The Fourth Affiliated Hospital of Harbin Medical University. Written informed consent was obtained from all patients.

Immunohistochemistry. Fresh tissue samples obtained by surgical excision were fixed in formalin and embedded in paraffin (Sigma-Aldrich, St. Louis, MO, USA) according to standard procedures. Sections $(4 \mu \mathrm{m})$ of representative blocks from each case were deparaffinized, rehydrated and immunostained by the peroxidase method. Slides were then incubated for 30 min with primary monoclonal antibodies: Rabbit anti-human c-erbB-2 (dilution, 1:250; catalogue number, BS8245-006) and rabbit anti-human MIF (dilution, 1:250; catalogue number, BS6432-100) purchased from
Beijing Boosen Biological Technology Co., Ltd. (Beijing, China). Control slides were incubated for the same period with non-immunized rabbit serum (negative control). Bound antibody complexes were stained for $10 \mathrm{~min}$ with $0.05 \%$ diaminobenzidine (Sigma-Aldrich). Sections were then briefly counterstained with hematoxylin (Sigma-Aldrich), mounted and examined under a Nikon Eclipse x400 microscope (Nikon, Tokyo, Japan). Positive MIF immunohistochemical staining was indicated by brown yellow granules in the cytoplasm or cell nucleus. Positive c-erbB-2 immunohistochemical staining was indicated by brown granules located in the cell membrane or cytoplasm. The expression intensity was determined by the degree of staining: No color (-); light color and positive cells $<5 \%(+)$; moderate staining, with positive cells between 5 and $50 \%(++)$; dark staining, with $>50 \%$ positive cells $(+++)$. The expression of HER-2 and MIF was classified into two levels, namely, low $(-$ or +$)$ or high $(++$ or +++$)$.

$R T-q P C R$. Following removing and cutting the uterus, a portion of the tissue $(0.5 \times 0.5 \mathrm{~cm})$ was immediately scraped into a small EP tube with RNA preservation solution and stored in a deep-freezer $\left(-80^{\circ} \mathrm{C}\right)$ until assayed. Total RNA from cells was isolated using TRIzol reagent (Fuzhou Maixin Biotechnology Development Co., Ltd., Fuzhou, China) according to the manufacturer's protocol. Equal quantities of RNA were reverse-transcribed and qPCR analysis was performed using qPCR Master-mix [2 $\mu 1$ templated cDNA reverse transcriptase, $0.5 \mu \mathrm{l}$ gene sense primers, $0.5 \mu \mathrm{l}$ gene antisense primer, $10 \mu 1$ Taq DNA polymerase (Shanghai Sangon Biological Engineering Technology \& Services Co., Ltd., Shanghai, China), $7 \mu$ l deionized water 10X PCR buffer and $1 \mu$ l SYBR Green (Thermo Fisher Scientific, Inc.)]. All primers were synthesized by Shanghai Invitrogen Biotechnology Co., Ltd. (Shanghai, China). The gene sequences were as follows: MIF, forward 5'-GCACAGCATCGGCAAGAT-3' and reverse 3'-GAGTTGTTCCAGCCCACATT-5'; c-erbB-2, forward 5'-CTGAACAATACCACCCCTGTC-3' and reverse 3'-AGA TGTCCTTCCACAAAATCGT-5'; GAPDH, forward 5'-AGG TGAAGGTCGGAGTCAAC-3' and reverse 3'-CGCTCC TGGAAGATGGTGAT-5'. PCR was performed in a PX2 thermacycler (Thermo Fisher Scientific, Inc., Waltham, MA, USA) The reaction conditions were as follows: Denaturation at $94^{\circ} \mathrm{C}$ for $1 \mathrm{~min}$; amplification and quantification: 30 cycles of $94^{\circ} \mathrm{C}$ for $30 \mathrm{sec}, 56^{\circ} \mathrm{C}$ for $30 \mathrm{sec}$ and $70^{\circ} \mathrm{C}$ for $40 \mathrm{sec}$; melting curve: $70^{\circ} \mathrm{C}$ for $7 \mathrm{~min}$. The conditions for c-erbB-2 were the same as MIF and GAPDH except the annealing temperature was $55^{\circ} \mathrm{C}$. The relative quantity of each target gene mRNA to the housekeeping gene (GAPDH) was calculated as $\Delta \mathrm{Cq}$, where $\Delta \mathrm{Cq}=\mathrm{Cq}$ gene - GAPDHCq. The fold change of each target gene mRNA to the corresponding normal tissue was calculated as $2^{(-\Delta \Delta \mathrm{Cq})}$, where $\Delta \Delta \mathrm{Cq}=\Delta \mathrm{Cq}$ target gene of the experimental group - $\Delta \mathrm{Cq}$ target gene in the control group.

Statistical analysis. Data were analyzed using SPSS version 17.0 software (SPSS, Inc., Chicago, IL, USA). MIF and c-erbB-2 mRNA expression results of the three groups of tissues are presented as the mean \pm standard deviation. Differences were analyzed using $\chi^{2}$ test and the two genes in each group were compared using independent samples t-test. 
Table I. Number of cases with a positive expression of MIF and c-erbB-2 in normal endometrium, atypical hyperplasia and endometrial carcinoma.

\begin{tabular}{lccccc}
\hline Group & No. of cases & MIF (+) & Positive (\%) & c-erbB-2 (+) & Positive (\%) \\
\hline Normal endometrium & 15 & 3 & 20 & 4 & 26.7 \\
Atypical hyperplasia & 20 & 9 & 45 & 7 & 35 \\
Endometrial cancer & 50 & 35 & 70 & 32 & 64 \\
\hline
\end{tabular}

MIF, macrophage migration inhibitory factor.

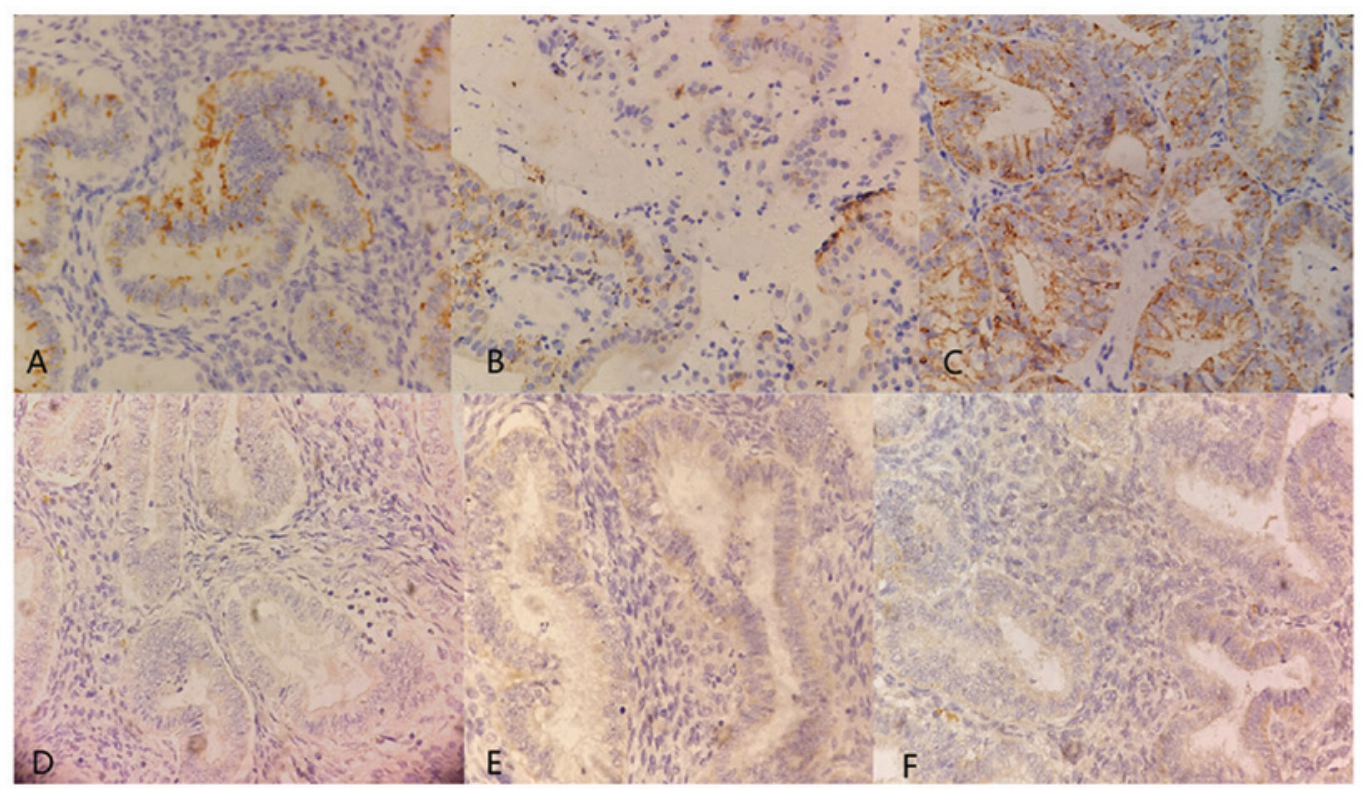

Figure 1. Analysis of MIF and c-erbB-2 protein expression in NE, endometrial hyperplasia and EC by immunohistochemistry. Brown yellow granules indicated positive staining. c-erbB-2 protein expression in (A) NE, (B) endometrial hyperplasia and (C) EC tissue. (D) MIF protein expression in (D) NE, (E) endometrial hyperplasia and (F) EC. Magnification, $x$ 400. Cells with brown granules were considered positively stained and the percentage of positively-stained cells was calculated. MIF, macrophage migration inhibitory factor; NE, normal endometrium; EC, endometrial carcinoma.

The correlation between the expression of MIF protein and c-erbB-2 protein was analyzed using McNemar's test. The confidence interval was $95 \%$ and $\mathrm{P} \leq 0.05$ was considered to indicate a statistically significant difference.

\section{Results}

Protein expression of $c$-erbB-2 and MIF. Immunoreactivities were scored under a light microscope at a magnification of $\mathrm{x} 400$ and the mean percentage of tumor cells that demonstrated positive staining was assessed. c-erbB-2 and MIF protein were detected in NE, atypical hyperplasia and EC (Fig. 1; Table I). The positive rates of MIF protein in NE, atypical hyperplasia and $\mathrm{EC}$ were 20,45 and $70 \%$, respectively $(\mathrm{P}=0.03)$. c-erbB-2 protein was positive in four normal cases $(26.7 \%)$, seven atypical hyperplasia cases (35\%) and $32 \mathrm{EC}$ cases $(64 \%)$.

MIF protein expression was significantly lower in endometrial carcinoma with early FIGO stages $(P=0.036)$, low grading $\mathrm{G} 1(\mathrm{P}=0.013)$ and no lymphovascular invasion $(\mathrm{P}=0.012)$. c-erbB-2 expression was significantly lower in endometrial carcinoma with early FIGO stages $(\mathrm{P}=0.036)$, depth of myometrial invasion $<0.4 \mathrm{~cm}(\mathrm{P}=0.007)$ and no lymphovascular invasion ( $\mathrm{P}=0.012$; Table II). However, no statistically significant difference was identified between the expression of MIF and c-erbB-2 in different age groups. Subsequently, the protein expression of MIF and c-erbB-2 was analyzed (Table III). When comparing MIF and c-erbB-2 protein expression with clinical stage, histological grade, depth of myometrial invasion and lymph node metastasis, it was found that MIF protein had a higher expression in tumors at stages I-II $\left(\chi^{2}=6.632 ; \mathrm{P}=0.01\right)$, grade $\mathrm{G} 1\left(\chi^{2}=11.064 ; \mathrm{P}=0.001\right)$ and with no lymph node metastasis $\left(\chi^{2}=6.556 ; \mathrm{P}=0.01\right)$. By contrast, c-erbB-2 protein expression was higher in tumors at stages III-IV $\left(\chi^{2}=4.800 ; \mathrm{P}=0.024\right)$, grade $\mathrm{G} 2-\mathrm{G} 3\left(\chi^{2}=6.788\right.$; $\mathrm{P}=0.009)$ and with lymph node metastasis $\left(\chi^{2}=6.149 ; \mathrm{P}=0.013\right)$. In addition, no consistency was observed between MIF and c-erbB-2 ( $\chi^{2}=3.35 ; \mathrm{P}<0.05$; Table IV).

mRNA expression of c-erbB-2 and MIF. DNA sequencing confirmed the amplification of the intended target sequence for MIF, c-erbB-2 and GAPDH. MIF mRNA and c-erbB-2 mRNA could be detected in all samples analyzed. GAPDH was used as the internal control gene for endometrial samples (Fig. 2). Normalized expression levels of MIF differed among 
Table II. Association between the protein expression of MIF and c-erbB-2 and the pathological characteristics of endometrial carcinoma.

\begin{tabular}{|c|c|c|c|c|c|c|c|c|c|}
\hline \multirow{2}{*}{$\begin{array}{l}\text { Clinical } \\
\text { feature }\end{array}$} & \multirow[b]{2}{*}{ Cases } & \multicolumn{4}{|c|}{ c-erbB-2 } & \multicolumn{4}{|c|}{ MIF } \\
\hline & & + & - & Positive (\%) & P-value ${ }^{a}$ & + & - & Positive (\%) & P-value \\
\hline \multicolumn{10}{|c|}{ Age (years) } \\
\hline$\leq 60$ & 28 & 18 & 10 & 64.3 & 0.962 & 19 & 9 & 78.6 & 0.709 \\
\hline$>60$ & 22 & 14 & 8 & 63.6 & & 16 & 6 & 63.6 & \\
\hline \multicolumn{10}{|c|}{ Stage (2009 FIGO) } \\
\hline I & 8 & 3 & 5 & 37.5 & 0.036 & 2 & 6 & 25.0 & 0.009 \\
\hline II & 30 & 18 & 12 & 60.0 & & 23 & 7 & 76.7 & \\
\hline III-IV & 12 & 11 & 1 & 91.7 & & 10 & 2 & 83.3 & \\
\hline \multicolumn{10}{|l|}{ Grade } \\
\hline G1 & 37 & 20 & 17 & 54.1 & 0.013 & 25 & 12 & 78.4 & 0.527 \\
\hline G2-G3 & 13 & 12 & 1 & 92.3 & & 10 & 3 & 76.9 & \\
\hline \multicolumn{10}{|c|}{$\begin{array}{l}\text { Myometrial } \\
\text { invasion }\end{array}$} \\
\hline$<0.4 \mathrm{~cm}$ & 29 & 17 & 12 & 58.6 & 0.352 & 16 & 13 & 55.2 & \\
\hline$>0.4 \mathrm{~cm}$ & 21 & 15 & 6 & 71.4 & & 19 & 2 & 90.5 & 0.007 \\
\hline \multicolumn{10}{|c|}{$\begin{array}{l}\text { Lymph node } \\
\text { metastasis }\end{array}$} \\
\hline No & 30 & 15 & 15 & 50.0 & 0.012 & 17 & 13 & 56.7 & \\
\hline Yes & 20 & 17 & 3 & 85.0 & & 18 & 2 & 90.0 & 0.012 \\
\hline
\end{tabular}

${ }^{\mathrm{a}} \mathrm{P} \leq 0.05$ was considered to indicate a statistically significant difference. MIF, macrophage migration inhibitory factor; FIGO, International Federation of Gynecology and Obstetrics.

the samples: The normal endometrial cancer tissue was used as a control and atypical hyperplasia samples demonstrated an average expression value of $1.798 \pm 1.216$, and EC samples had an expression value of $2.494 \pm 1.108$. The c-erbB- 2 mRNA expression value in the atypical hyperplasia and EC samples was $1.808 \pm 1.127$ and $3.147 \pm 1.471$, respectively. The MIF and c-erbB-2 mRNA expression levels were upregulated in EC samples, in comparison with in atypical hyperplasia and normal endometrium $(\mathrm{P}<0.05)$.

MIF mRNA and c-erbB-2 mRNA levels were also analyzed according to the following parameters of EC samples: Age, clinical stage, histological grade, depth of myometrial invasion and lymph node metastasis (Fig. 3). The analysis of MIF mRNA expression demonstrated no statistically significant difference in the age and depth of myometrial invasion (P>0.05). MIF mRNA overexpression appeared to correlate with lower aggressiveness: It was significantly associated with early FIGO stages, $(\mathrm{P}=0.001)$, low grading $\mathrm{G} 1(\mathrm{P}=0.004)$ and no lymphovascular invasion $(\mathrm{P}=0.012)$. It was observed that c-erbB-2 mRNA levels had no difference in age $(\mathrm{P}>0.05)$. The analysis demonstrated that the levels of c-erbB-2 mRNA were higher in FIGO stages III-IV, grading G2-3, deeper invasion and lymphovascular invasion, compared with early FIGO stages, low grading G1, a depth of myometrial invasion $<0.4 \mathrm{~cm}$ and no lymphovascular invasion, respectively $(3.354 \pm 1.254 \mathrm{vs}$. $2.953 \pm 1.686, \mathrm{P}=0.630 ; 2.291 \pm 1.231$ vs. $4.323 \pm 1.221, \mathrm{P}=0.001$; $2.323 \pm 1.264$ vs. $4.263 \pm 1.250, \mathrm{P}=0.003 ; 2.459 \pm 1.307$ vs. $4.028 \pm 1.397, \mathrm{P}=0.033 ; 2.352 \pm 1.389$ vs. $4.067 \pm 1.284, \mathrm{P}=0.024)$.

\section{Discussion}

Several studies have demonstrated that the c-erbB-2 gene is associated with the metastasis and invasion of breast cancer, which reflects the potential ability of local growth, invasion and lymphatic metastasis of this tumor $(25,26)$. It may therefore be a detection index of early recurrence, shorter survival rate and prognosis. Another study demonstrated that c-erbB-2 had a significantly higher expression in breast cancer with bone metastasis $(\mathrm{P}=0.029)(27)$. The study also demonstrated that c-erbB-2 contributed to tumor invasion and metastasis, and thus can be used as a prognostic indicator. A previous study confirmed that the angiogenic microvessel density was significantly higher in breast cancer patients with overexpression of c-erbB-2 protein, compared with the c-erbB-2 negative groups $(\mathrm{P}<0.05)(28)$. Therefore, $\mathrm{c}-\mathrm{erbB}-2$ is an independent prognostic indicator in breast cancer.

The present study demonstrated that c-erbB-2 is associated with clinical stage, histological grade, lymph node metastasis $(\mathrm{P}<0.05)$, but not with age and depth of myometrial invasion $(\mathrm{P}>0.05)$. In addition, c-erbB-2 had a higher expression in tumors with FIGO stages III-IV, grade G2-3, deeper invasion and lymphovascular invasion. This was confirmed in a previous study (29). Morrison et al analyzed 110 cases of endometrial cancer and the experimental results demonstrated that c-erbB-2 was correlated with histological grade (the positive rate of G1 tumor was significantly higher than G2 and G3 tumor), but not with age, clinical stage, histological type or the depth of 
Table III. Comparison between the protein expression of MIF and c-erbB-2 and the pathological characteristics of EC.

\begin{tabular}{|c|c|c|c|c|c|c|c|c|c|c|}
\hline \multirow[b]{2}{*}{ Clinical feature } & \multicolumn{4}{|c|}{ c-erbB-2 } & \multirow[b]{2}{*}{ P-value } & \multicolumn{4}{|c|}{ MIF } & \multirow[b]{2}{*}{ P-value ${ }^{a}$} \\
\hline & Cases $(+)^{\mathrm{b}}$ & Low & High & $\chi^{2}$ & & Cases $(+)^{\mathrm{b}}$ & Low & High & $\chi^{2}$ & \\
\hline \multicolumn{11}{|l|}{ Age (years) } \\
\hline$\leq 60$ & 18 & 10 & 8 & 0.508 & 0.722 & 19 & 11 & 8 & 2.485 & 0.115 \\
\hline$>60$ & 14 & 6 & 8 & & & 16 & 5 & 11 & & \\
\hline \multicolumn{11}{|c|}{ Stage (2009 FIGO) } \\
\hline I-II & 21 & 14 & 7 & 6.788 & 0.009 & 25 & 8 & 17 & 6.632 & 0.010 \\
\hline III-IV & 11 & 2 & 9 & & & 10 & 8 & 2 & & \\
\hline \multicolumn{11}{|l|}{ Grade } \\
\hline G1 & 20 & 13 & 7 & 4.800 & 0.028 & 25 & 7 & 18 & 11.064 & 0.001 \\
\hline G2-G3 & 12 & 3 & 9 & & & 10 & 9 & 1 & & \\
\hline \multicolumn{11}{|c|}{ Myometrial invasion } \\
\hline$<0.4 \mathrm{~cm}$ & 17 & 7 & 10 & 1.129 & 0.479 & 16 & 4 & 12 & 5.096 & 0.024 \\
\hline$>0.4 \mathrm{~cm}$ & 15 & 9 & 6 & & & 19 & 12 & 7 & & \\
\hline \multicolumn{11}{|l|}{$\begin{array}{l}\text { Lymph node } \\
\text { metastasis }\end{array}$} \\
\hline No & 15 & 11 & 4 & 6.149 & 0.013 & 17 & 4 & 13 & 6.556 & 0.010 \\
\hline Yes & 17 & 5 & 12 & & & 18 & 12 & 6 & & \\
\hline
\end{tabular}

${ }^{\mathrm{a}} \mathrm{P} \leq 0.05$ was considered to indicate a statistically significant difference. ${ }^{\mathrm{b}} \mathrm{Number}$ of cases with a positive expression of MIF or c-erbB-2. MIF, macrophage migration inhibitory factor; FIGO, International Federation of Gynecology and Obstetrics; EC, endometrial carcinoma.

Table IV. Correlation between MIF and c-erbB-2.

\begin{tabular}{lcrc}
\hline & \multicolumn{3}{c}{ MIF } \\
\cline { 2 - 4 } c-erbB-2 & + & - & Total \\
\hline+ & 25 & 7 & 15 \\
- & 10 & 8 & 18 \\
Total & 35 & 15 & 18
\end{tabular}

MIF, macrophage migration inhibitory factor.

myometrial invasion (30). In regards to the high expression level in G1, this study contrasts with the results of the present study.

To the best of our knowledge, there is only one study focusing on MIF in endometrial cancer: Bondza et al found that MIF treatment significantly stimulated vascular endothelial growth factor expression in a dose- and time-dependent manner in EC (31). A previous study associated MIF with tumor growth and progression by stimulating tumor-associated angiogenesis, but not in endometrial cancer. Hagemann et al observed that MIF was strongly expressed in malignant ascites, and that MIF generated by ovarian cancer cells could stimulate the expression of cytokines, chemokines and tumor angiogenesis factors, and contribute towards the vascularization and angiogenesis of tumors (32). The authors found that MIF was strongly expressed in malignant ascites, which suggests that MIF autocrine generated by ovarian cancer cells stimulated other cytokines, chemokines, angiogenesis factor, and contributed to the vascularization and angiogenesis of the tumor (32). Nishihira et al concluded that MIF is closely associated with tumor growth and angiogenesis through the treatment of mice colon cancer cells with the antisense MIF gene (33). This study demonstrated that MIF can promote tumor angiogenesis, growth, invasion and metastasis.

The presence of MIF mRNA and protein could be observed in all endometrial samples. The overexpression of MIF mRNA and protein is associated with low histological grade, early FIGO stages and no lymphovascular invasion $(\mathrm{P}<0.05)$. Similarly, previous studies found that MIF overexpression correlates with lower aggressiveness and was significantly associated with early FIGO stage, low grading G1-2, no lymphovascular invasion and confirms the data reported by other authors on other tumor types $(21,34,35)$. This suggests that, in patients with endometrial cancer, the upregulation of MIF may be associated with the inhibition of metastatic spread.

Finally, the correlation between MIF and c-erbB-2 was analyzed and no significant association was found between them $\left(\chi^{2}=3.35 ; \mathrm{P}>0.05\right)$. In the mouse model of HER2-driven breast cancer, Schulz et al concluded that HER2 overexpression can inhibit MIF activity (36). The present study failed to come to this conclusion. Since the amount of endometrial hyperplasia is not sufficient, the samples can not be divided into groups of more detail, and thus the association between the expression of MIF and c-erbB-2 in endometrial hyperplasia cannot be confirmed.

To the best of our knowledge, the present study is the first to focus on the conjoint analysis of MIF and c-erbB-2 by RT-qPCR and immunohistochemistry. In our population study, the results are consistent between these two types 


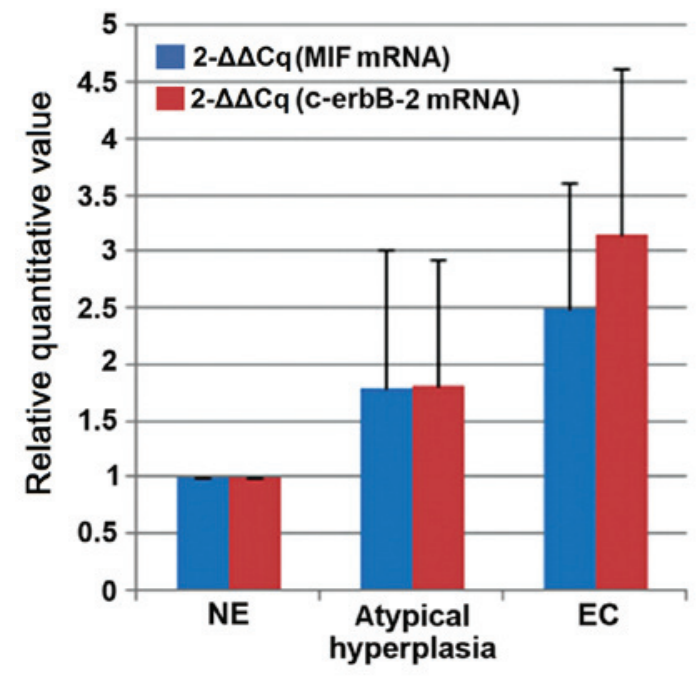

Figure 2. Reverse transcription quantitative polymerase chain reaction was used to determine the expression of MIF and c-erbB-2 mRNA in NE, endometrial hyperplasia and EC. The normal sample was used as a control. The relative quantity of each target gene mRNA to the housekeeping gene (GAPDH) was calculated as $\Delta \mathrm{Cq}$, where $\Delta \mathrm{Cq}=\mathrm{Cq}$ gene - GAPDHCq. The fold change of each target gene mRNA to the corresponding normal tissue was calculated as $2^{-\Delta \Delta \mathrm{Cq}}$, where $\Delta \Delta \mathrm{Cq}=\Delta \mathrm{Cq}$ target gene of the experimental group $-\Delta \mathrm{Cq}$ target gene in the control group. Blue indicates MIF gene content, red shows c-erbB-2 gene expression. The data are presented as the mean \pm standard deviation and their differences were analyzed using $\chi^{2}$ test, $\mathrm{P} \leq 0.05$ was considered to indicate a statistically significant difference. The MIF mRNA (red) and c-erbB-2 mRNA (blue) expression levels (fold increase relative to GAPDH) were all upregulated in EC compared with in endometrial hyperplasia and NE $(\mathrm{P}<0.05)$. MIF, macrophage migration inhibitory factor; NE, normal endometrium; EC, endometria carcinoma.

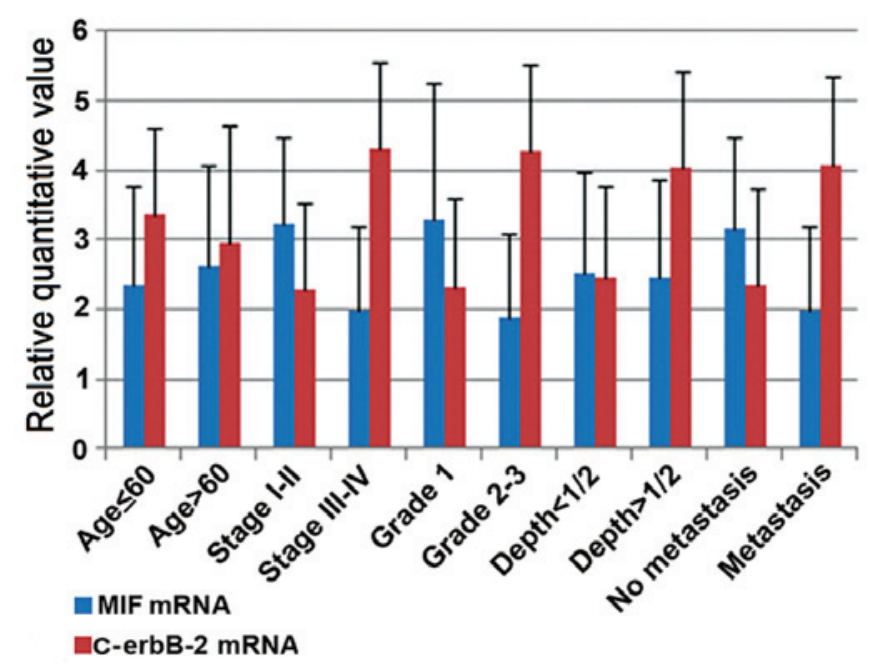

Figure 3. Abscissa indicates pathological characteristics, the vertical axis represents gene content. The expression of MIF (blue) and c-erbB-2 (red) in endometrial carcinoma was compared with pathological characteristics, including age, FIGO stage, histological grade, depth of myometrial invasion and lymph node metastasis. The two genes in each group were compared using an independent samples t-test. MIF overexpression is significantly associated with characteristics of low invasiveness, including early stage, low grading and no lymphovascular invasion $(\mathrm{P}<0.05)$, whereas c-erbB-2 mRNA levels were higher in tumors with FIGO stages III-IV, grading G2-3, deeper invasion and lymphovascular invasion, compared with tumors with early FIGO stages, low grading G1, depth of myometrial invasion $<0.4 \mathrm{~cm}$ and no lymphovascular invasion. MIF, macrophage migration inhibitory factor; FIGO, International Federation of Gynecology and Obstetrics. of test. MIF and c-erbB-2 were overexpressed in endometrial cancer samples suggesting that MIF and c-erbB-2 are involved in the occurrence and development of tumors. It is hypothesized that the imbalance in the expression of MIF and c-erbB-2 could be a possible critical step in the progression of endometrial cancer. Although this hypothesis needs to be confirmed in a larger number of cases, it may be clinically relevant.

These data suggest that overexpression of MIF and c-erbB-2 is associated with the occurrence and development of endometrial cancer. The upregulation of MIF may be associated with the inhibition of metastatic spread, however, upregulation of MIF may promote tumor progression. In conclusion, MIF and c-erbB-2 are correlated with the occurrence and the development of endometrial cancer, and thus can be used for the early diagnosis and prognosis of endometrial cancer. However, the detailed functional significance of MIF and c-erbB-2 in endometrial cancer remains to be determined. Taken together, the current aim is to identify new prognostic factors to customize adjuvant therapies and new targets for anticancer therapies.

\section{Acknowledgements}

This study was supported by the Science Foundation of Heilongjiang Province of China (grant no. H201429).

\section{References}

1. Jemal A, Bray F, Center MM, Ferlay J, Ward E and Forman D: Global cancer statistics. CA Cancer J Clin 61: 69-90, 2011.

2. Mhawech-Fauceglia P, Wang D, Samrao D, Godoy H, Pejovic T, Liu S and Lele S: Pair-Box (PAX8) protein positive expression is associated with poor disease outcome in women with endometrial cancer. Br J Cancer 107: 370-374, 2012.

3. Verit FF and Yucel O: Endometriosis, leiomyoma and adenomyosis: The risk of gynecologic malignancy. Asian Pac J Cancer Prev 14: 5589-5597, 2013.

4. $\mathrm{Xu} \mathrm{Z}$ and Ford BD: Uperegulation of erbB recepters in rat brain after middle cerebrial arterial occlusion. Neurosci Lett 375: 181-186, 2005.

5. Araújo A, Ribeiro R, Azevedo I, Coelho A, Soares M, Sousa B, Pinto D, Lopes C, Medeiros R and Scagliotti GV: Genetic polymorphisms of the epidermal growth factor and related receptor in non-small cell lung cancer-a review of the literature. Oncologist 12: 201-210, 2007.

6. Oshima CT, Lanzoni VP, Iriya K and Forones NM: C-erbB-2 oncoprotein expression in gastric carcinoma: Correlation with clinical stage and prognosis. Int J Biol Markers 16: 250-254, 2001.

7. Potti A, Forseen SE, Koka VK, Pervez H, Koch M, Fraiman G, Mehdi SA and Levitt R: Determination of HER-2/neu overexpression and clinical predictors of survival in a cohort of 347 patients with primary malignant brain tumors. Cancer Invest 22: 537-544, 2004.

8. Rotter M, Block T, Busch R, Thanner S and Höfler H: Expression of Her-2/neu in renal-cell carcinoma. Correlation with histologic subtypes and differentiation. Int J Cancer 52: 213-217, 1992.

9. Manavi M, Bauer M, Baghestanian M, Berger A, Kucera E, Pischinger K, Battistutti W and Czerwenka K: Oncogenic potential of c-erbB-2 and its association with c-K-ras in premalignant and malignant lesions of the human uterine endometrium. Tumour Biol 22: 299-309, 2001.

10. Xi L, Satpathy M,Zhao Q, Qian W, Yang L and Jiang H: HER-2/neu targeted delivery of a nanoprobe enables dual photoacoustic and fluorescence tomography of ovarian cancer. Nanomedicine 10: 669-677, 2014.

11. Carson WE, PariharR, Lindemann MJ, Personeni N, Dierksheide J, Meropol NJ,Baselga J and Caligiuri MA: Interleukin-2 enhances the natural killer cell response to Herceptin-coated Her2/neu-positive breast cancer cells. Eur J Immunol 31: 3016-3025, 2001. 
12. Slamon DJ, Leyland-Jones B, Shak S, Fuchs H, Paton V, Bajamonde A, Fleming T, Eiermann W, Wolter J, Pegram M, et al: Use of chemotherapy plus a monoclonal antibody against HER2 for metastatic breast cancer that overexpresses HER2. N Engl J Med 344: 783-792, 2001.

13. Apte RS, Sinha D, Mayhew E, Wistow GJ and Niederkorn JY: Cutting edge: Role of macrophage migration inhibitory factor in inhibiting NK cell activity and preserving immune privilege. J Immunol 160: 5693-5696, 1998.

14. Rendon BE, Roger T, Teneng I, Zhao M, Al-Abed Y, Calandra T and Mitchell RA: Regulation of human lung adenocarcinoma cell migration and invasion by macrophage migration inhibitory factor. J Biol Chem 282: 29910-29918, 2007.

15. Liao H, Bucala R and Mitchell RA: Adhesion-dependent signaling by macrophage migration inhibitory factor (MIF). J Biol Chem 278: 76-81,2003.

16. Amin MA, Volpert OV, Woods JM, Kumar P, Harlow LA and Koch AE: Migration inhibitory factor mediates angiogenesis via mitogen-activated protein kinase and phosphatidylinositol kinase. Circ Res 93: 321-329, 2003.

17. Baumann R, Casaulta C, Simon D, Conus S, Yousefi S and Simon HU: Macrophage migration inhibitory factor delays apoptosis in neutrophils by inhibiting the mitochondria-dependent death pathway. FASEB J 17: 2221-2230, 2003.

18. Bacher M, Schrader J, Thompson N, Kuschela K, Gemsa D, Waeber G and Schlegel J: Up-regulation of macrophage migration inhibitory factor gene and protein expression in glial tumour cells during hypoxic and hypoglycemic stress indicates a critical role for angiogenesis in glioblastoma multiforme. Am J Pathol 162: 11-17, 2003

19. Repp AC, Mayhew ES, Apte S and Niederkorn JY: Human uveal melanoma cells produce macrophage migration-inhibitory factor to prevent lysis by NK cells. J Immunol 165: 710-715, 2000

20. Krockenberger M, Dombrowski Y, Weidler C, Ossadnik M, Hönig A, Häusler S, Voigt H, Becker JC, Leng L, Steinle A, et al: Macrophage migration inhibitory factor contributes to the immune escape of ovarian cancer by down-regulating NKG2D. J Immunol 180: 7338-7348, 2008

21. Xia HH, Yang Y, Chu KM, Gu Q, Zhang YY, He H, Wong WM, Leung SY, Yuen ST, Yuen MF, et al: Serum macrophage migration-inhibitory factor as a diagnostic and prognostic biomarker for gastric cancer. Cancer 115: 5441-5449, 2009.

22. White ES, Flaherty KR, Carskadon S, Brant A, Iannettoni MD Yee J, Orringer MB and Arenberg DA: Macrophage migration inhibitory factor and CXC chemokine expression in non-small cell lung cancer: Role in angiogenesis and prognosis. Clin Cancer Res 9: 853-860, 2003.

23. Zheng J and Zhu YM: Expression of c-erbB-2 proto-oncogene in extrahepatic cholangiocarcinoma and its clinical significance. Hepatobiliary Pancreat Dis Int 6: 412-415, 2007.
24. Wu S, Lian J, Tao H, Shang $\mathrm{H}$ and Zhang L: Correlation of macrophage migration inhibitory factor gene polymorphism with the risk of early-stage cervical cancer and lymphatic metastasis. Oncol Lett 2: 1261-1267, 2011.

25. Lambropoulou M, Stefanou D, Alexiadis G, Tamiolakis D, Tripsianis G,ChatzakiE, Vandoros GP, Kiziridou A,Papadopoulou E and Papadopoulos N: Cytoplasmic expression of c-erbB-2 in endometrial carcinomas. Onkologie 30: 495-500, 2007.

26. Bhatavdekar JM, Patel DD, Shah NG, Vora HH, Suthar TP, Chikhlikar PR, Ghosh N and Trivedi TI: Prognostic significance of immunohistochemically localized biomarkers in stage II and stage III breast cancer. A multivariate analysis. Ann Surg Oncol 7: 305-311, 2000.

27. Kim R, Arihiro K, Emi M, Tanabe K and Osaki A: Potential role of HER-2; in primary breast tumor with bone metastasis. Oncol Rep 15: 1477-1484, 2006.

28. Pérez-Regadera J, Sánchez-Muñoz A, De-la-Cruz J, Ballestín C, Lora D, García-Martín R, Mendiola C, Alonso L, Alba E and Lanzós E: Negative prognostic impact of the coexpression of epidermal growth factor receptor and c-erbB-2 in locally advanced cervical cancer. Oncology 76: 133-141, 2009.

29. Toi M, Kashitani T and Tominaga T: Tumor angiogenesis is an independent prognostic indicator in primary breast carcinoma. Int J Cancer 55: 371-374, 1993.

30. Morrison C, Zanagnolo V, Ramirez N, Cohn DE, Kelbick N, Copeland L, Maxwell GL and Fowler JM: HER-2 is an independent prognostic factor in endometrial cancer: Association with outcome in a large cohort of surgically staged patients. J Clin Oncol 24: 2376-2385, 2006

31. Bondza PK, Metz CN and Akoum A: Macrophage migration inhibitory factor upregulates alpha(v)beta (3) integrin and vascular endothelial growth factor expression in endometrial adenocarcinoma cell line Ishikawa. J Reprod Immunol 77: 142-151, 2008.

32. Hagemann T, Robinson SC, Thompson RG, Charles K, Kulbe H and Balkwill FR: Ovarian cancer cell-derived migration inhibitory factor enhances tumor growth, progression and angiogenesis. Mol Cancer Ther 6: 1993-2002, 2007.

33. Nishihira J, Ishibashi T, Fukushima T, Sun B, Sato Y and Todo S: Macrophage migration inhibitory factor (MIF): Its potential role in tumor growth and tumor-associated angiogenesis. Ann NY Acad Sci 995: 171-182, 2003

34. Denz A, Pilarsky C, Muth D, Rückert F, Saeger HD and Grützmann R: Inhibition of MIF leads to cell cycle arrest and apoptosis in pancreatic cancer cells. J Surg Res 160: 29-34, 2010

35. Verjans E, Noetzel E, Bektas N, Schütz AK, Lue H, Lennartz B, Hartmann A, Dahl E and Bernhagen J: Dual role of macrophage migration inhibitory factor (MIF) in human breast cancer. BMC Cancer 9: 230, 2009.

36. Schulz R, Streller F, Scheel AH, Rüschoff J, Reinert MC, Dobbelstein M, Marchenko ND and Moll UM: HER2/ErbB2 activates HSF1 and thereby controls HSP90 clients including MIF in HER2-overexpressing breast cancer. Cell Death Dis 5: e980, 2014. 